\title{
Infiltration of CD1a-positive dendritic cells in advanced laryngeal cancer correlates with unfavorable outcomes post- laryngectomy
}

\author{
Akimichi Minesaki $^{1,2}$, Keita Kai $^{3^{*}}$ (D) Yuichiro Kuratomi ${ }^{2}$ and Shinichi Aishima ${ }^{1,3}$
}

\begin{abstract}
Background: The prognosis of advanced laryngeal cancer is unfavorable despite advances in multidisciplinary therapy. Dendritic cells (DCs) play a central role in antitumor immunity. Tumor-infiltrating CD1a ${ }^{+}$DCs have been reported to be associated with clinical outcomes in carcinomas of various organs, but the clinical impact of CD1a ${ }^{+}$ DCs in laryngeal cancer remains to be unequivocally established.

Methods: We retrospectively analyzed the cases of 57 patients with Stage III or IV laryngeal cancer who underwent a total laryngectomy. Immunohistochemistry detection of CD1a, S100 and CD8 was performed on representative resected specimens. $\mathrm{CD} 1 \mathrm{a}^{+} \mathrm{DCs}, \mathrm{S100}^{+} \mathrm{DCs}$ and $\mathrm{CD}^{+}$cytotoxic T-lymphocytes (CTLS) were evaluated, and the cases divided into high and low groups according to the cut-off of the median values for each of these 3 parameters.

Results: Compared to the CD1a-low group, the CD1a-high group had more advanced cases and showed significantly worse disease-specific survival (DSS) $(P=0.008)$ and overall survival $(O S)(P=0.032)$. The analyses of S100 DCs and CD8 ${ }^{+}$CTLs revealed no significant impact on clinical outcomes. However, multivariate analysis revealed that infiltration of $C D 1 a^{+}$DCs was an independent unfavorable prognostic factor for both DSS $(P=0.009)$ and OS $(P=0.013)$.

Conclusions: Our results demonstrated that the infiltration of $C D 1 a^{+} D C s$ was associated with unfavorable clinical outcomes in patients with advanced laryngeal cancer who underwent a total laryngectomy as the initial treatment.
\end{abstract}

Keywords: Laryngeal cancer, CD1a, Dendritic cell, Prognosis, Immunohistochemistry

\section{Background}

Laryngeal cancer is the second most common malignancy of head and neck cancer, with thyroid cancer being the first [1]. Although laryngeal cancer accounts for only $0.9 \%$ of cancers in men and $0.2 \%$ in women, circa 4800 patients are newly diagnosed with laryngeal cancer

\footnotetext{
* Correspondence: kaikeit@cc.saga-u.ac.jp

${ }^{3}$ Department of Pathology, Saga University Hospital, Nabeshima 5-1-1, Saga City, Saga 849-8501, Japan

Full list of author information is available at the end of the article
}

every year in Japan [2]. The 5-year survival rate of early laryngeal cancer (Stages I and II in the TNM classification) is favorable (> 80\%), but the prognosis of advanced laryngeal cancer (Stages III and IV in the TNM classification) is poor, and its 5-year survival rate remains around $50 \%$, despite much progress being made in multidisciplinary therapy such as combinations of chemo-radiotherapy and surgery [3]. The establishment of distinct prognostic factors and the development of novel treatments for advanced laryngeal cancer are

C C The Author(s). 2021 Open Access This article is licensed under a Creative Commons Attribution 4.0 International License, which permits use, sharing, adaptation, distribution and reproduction in any medium or format, as long as you give appropriate credit to the original author(s) and the source, provide a link to the Creative Commons licence, and indicate if changes were made. The images or other third party material in this article are included in the article's Creative Commons licence, unless indicated otherwise in a credit line to the material. If material is not included in the article's Creative Commons licence and your intended use is not permitted by statutory regulation or exceeds the permitted use, you will need to obtain permission directly from the copyright holder. To view a copy of this licence, visit http://creativecommons.org/licenses/by/4.0/. The Creative Commons Public Domain Dedication waiver (http://creativecommons.org/publicdomain/zero/1.0/) applies to the data made available in this article, unless otherwise stated in a credit line to the data. 
important for the proper assessment of prognosis and for decision making about the most appropriate therapeutic regimen.

Cancer immunity plays an important role in the suppression of invasion and proliferation of solid tumors, but some types of cancer cells develop immune tolerance and can escape the $\mathrm{T}$-cell mediated antitumor immune response $[4,5]$. It is thus necessary to determine the precise status of the immune response in patients with advanced laryngeal cancer; doing so is likely to contribute to the development of distinct prognostic factors and/or novel treatments. In the present study, we focused on dendritic cells (DCs) in laryngeal cancer, which are generally considered to be central regulators of anticancer immune responses [6]. DCs are antigen-presenting cells that activate cytotoxic T-lymphocytes (CTLs) through the major histocompatibility complex class I and class II molecules [7]. DCs also directly activate B lymphocytes [8] and can activate innate immune cells such as natural killer cells and natural killer $\mathrm{T}$ cells $[9,10]$. Thus, DCs are considered to play a central role in antitumor immunity.

CD1a is a transmembrane glycoprotein that is associated with the antigen presentation of DCs. In contrast to the S100 protein, which is usually expressed on both immature and mature DCs [11], CD1a is considered to be specifically expressed on immature DCs [12]. However, CD1a remains one of the most poorly understood molecules in terms of its functional roles, even though it was first described in 1982 [12]. Several reports have indicated that the infiltration of CD1a-positive $\left(\mathrm{CD}^{2} \mathrm{a}^{+}\right) \mathrm{DCs}$ into tumor tissue is associated with favorable clinical outcomes in carcinomas of the ovary [13], oral cavity $[14,15]$, thyroid [16] and gallbladder [17]. However, the roles of tumor-infiltrating $\mathrm{CD} \mathrm{a}^{+}$ DCs and their clinical impact on patients with laryngeal cancer remain to be elucidated. We conducted the present study to: (1) assess the status of tumor infiltrating $\mathrm{CD}^{+} \mathrm{a}^{+}$ DCs in patients with advanced laryngeal cancer; and (2) to clarify the relationships between $\mathrm{CD} 1 \mathrm{a}^{+} \mathrm{DCs}$ and clinicopathological characteristics including outcomes.

\section{Methods}

\section{Patients}

The initial enrollees were 656 patients with laryngeal cancer who were treated at Saga University Hospital between 1990 and 2016. Among them, we excluded neoadjuvant cases including those treated with chemotherapy with or without radiotherapy, because the microenvironment of tumors may be different between treatment naïve and neoadjuvant cases. The 93 patients who underwent a total laryngectomy as the initial treatment for laryngeal cancer were assessed; there were 33 cases at Stage II, 22 cases at Stage III and 38 cases at Stage IV, based on the TNM classification (8th ed.) [18]. We excluded Stage II cases because none of these patients died from cancer progression. Of the remaining 60 cases with Stage III and IV laryngeal cancers, 3 were excluded because of the unavailability of cancer tissue specimens. A final total of 57 total laryngectomy cases with Stage III or IV laryngeal cancer were retrospectively analyzed. Comprehensive informed consent for the use of resected tissue for research was obtained from all patients, and the study protocol was approved by the Ethics Committee of the Faculty of Medicine at Saga University (No. 2020-04-R-19).

\section{Immunohistochemistry}

Sections $(4-\mu \mathrm{m})$ of formalin-fixed paraffin-embedded specimens of representative cancer tissue from each patient's case were used for immunohistochemistry (IHC). The primary antibodies used were CD1a (Clone010, Ready to use; Dako, Glostrup, Denmark), and CD8 (CloneC8/144B, Ready to use; Dako). IHC was performed using an Autostainer plus ${ }^{\circ}$ automatic stainer (Dako). The Envision $^{+\infty}$ System (Dako) was employed as the secondary antibody. Specimens on slides were visualized after diaminobenzidine tetrahydrochloride staining, and nuclei were counterstained with hematoxylin.

\section{Assessment of DCs and $\mathrm{CD}^{+}$CTLs}

For the evaluation of $\mathrm{CD}_{1} \mathrm{a}^{+}$and $\mathrm{S} 100^{+} \mathrm{DCs}$, digital images of 3 hot spots of DC infiltration of tumor tissue

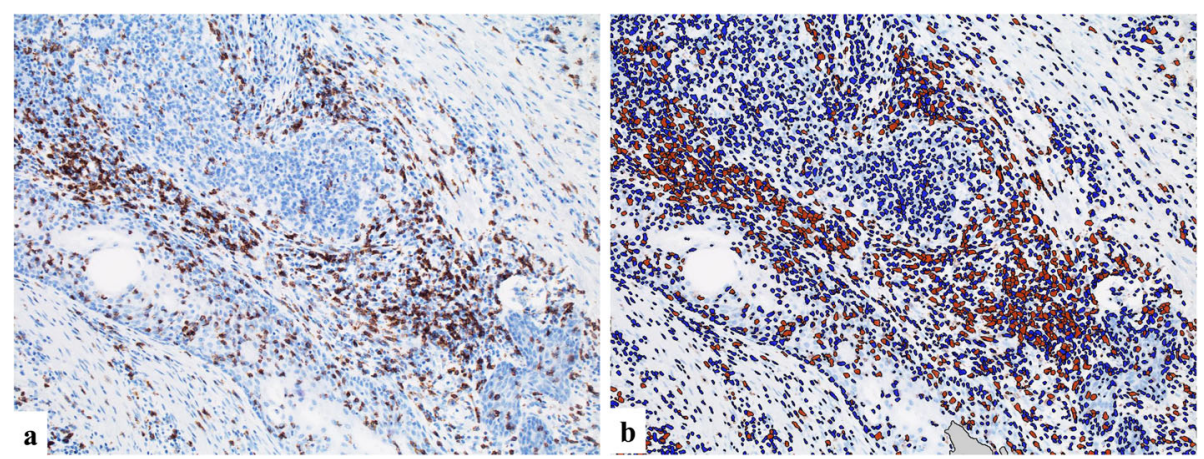

Fig. 1 Representative analyzing images for CD8 ${ }^{+}$CTLs. a Digital image of IHC for CD8 (×200). b CD8 $8^{+}$CTLs automatically detected (orange) by image analysis software (Tissue Studio) 
were taken on a light microscope $(\times 100$ magnification) for each patient. The number of DCs was counted in each digital image and the average number in the 3 digital images was calculated for each case. For the evaluation of $\mathrm{CD}^{+}$CTLs, digital photographs of 3 hot spots of CTL infiltration of tumor tissue were taken on a light microscope ( $\times 200$ magnification). The average number of tumor-infiltrating $\mathrm{CD}^{+}$CTLs in 3 digital images was automatically calculated by image analysis software (Tissue Studio, Definiens, Munchen, Germany). Representative analyzed images are shown in Fig. 1. We divided the patients into pairs of groups based on the median value for each assessment of $\mathrm{CD}^{+} \mathrm{a}^{+}, \mathrm{S} 100^{+}$and $\mathrm{CD}^{+}$cells.

\section{Statistical analysis}

All statistical analyses were performed using JMP Pro 13.1.0 software (SAS Institute, Cary, NC, US). A Student's $t$-test, Pearson's chi-squared test and a linear regression analysis were used when appropriate for comparisons between 2 groups. Disease-specific survival (DSS) was defined as the period from surgery to cancer-related death or the last follow-up. Overall survival (OS) was defined as the period from surgery to death or the last follow-up. The maximum followup period in the study was 120 months, with a median follow-up time of 45.2 months. The survival curve was calculated by the Kaplan-Meier method, and a log-rank test was also conducted. Univariate and multivariate analyses were performed using a Cox proportional hazard model. Significant variables in the univariate analyses were selected for the multivariate analysis. $P$-values $<0.05$ were considered to be significant.

\section{Results}

\section{Clinicopathological features of the 57 patients with} advanced laryngeal cancer

The clinicopathological features of the 57 patients with advanced laryngeal cancer are summarized in Table 1. Fifty-four patients (94.7\%) were male and the remaining $3(5.3 \%)$ were female. The mean age at the time of surgery was 68.4 years. The most frequent primary tumor site was the glottis $(n=35)$, followed by the supraglottis $(n=16)$ and the subglottis $(n=6)$. Regarding $\mathrm{T}$ stage, 4 cases $(7.0 \%)$ were categorized as T2, 22 cases $(38.6 \%)$ as T3, and 31 cases $(54.4 \%)$ as T4. Thirty-seven cases $(64.9 \%)$ had no lymph-node metastasis at the time of surgery. Only 1 patient had distant metastasis. Twenty cases (35.1\%) were categorized as Stage III and the remaining 37 cases $(64.9 \%)$ as Stage IV. The histology of all 57 cases was squamous cell carcinoma (SCC) and its histological differentiation was
Table 1 Clinicopathological features of 57 patients with laryngeal cancer

\begin{tabular}{|c|c|}
\hline Age, years (mean $\pm S D$ ) & $68.4 \pm 8.8$ \\
\hline \multicolumn{2}{|l|}{ Sex } \\
\hline Male & $54(94.7 \%)$ \\
\hline Female & $3(5.3 \%)$ \\
\hline \multicolumn{2}{|l|}{ Smoking habit } \\
\hline Never & $5(8.8 \%)$ \\
\hline Ex & $19(33.3 \%)$ \\
\hline Current & $33(57.9 \%)$ \\
\hline \multicolumn{2}{|l|}{ Alcohol abuse } \\
\hline$(+)$ & $35(61.4 \%)$ \\
\hline$(-)$ & $22(38.6 \%)$ \\
\hline \multicolumn{2}{|l|}{ Subsite } \\
\hline Glottis & $35(61.4 \%)$ \\
\hline Supraglottis & $16(28.1 \%)$ \\
\hline Subglottis & $6(10.5 \%)$ \\
\hline \multicolumn{2}{|l|}{ Histology ${ }^{a}$} \\
\hline Well & $30(52.6 \%)$ \\
\hline Mode & $25(43.9 \%)$ \\
\hline Poor & $2(3.5 \%)$ \\
\hline \multicolumn{2}{|l|}{ T stage } \\
\hline $\mathrm{T} 2$ & $4(7.0 \%)$ \\
\hline $\mathrm{T} 3$ & $22(38.6 \%)$ \\
\hline T4 & $31(54.4 \%)$ \\
\hline \multicolumn{2}{|l|}{$\mathrm{N}$ stage } \\
\hline No & $37(64.9 \%)$ \\
\hline N1 & $5(8.8 \%)$ \\
\hline N2 & $14(24.6 \%)$ \\
\hline N3 & $1(1.8 \%)$ \\
\hline \multicolumn{2}{|l|}{ M stage } \\
\hline MO & $56(98.2 \%)$ \\
\hline M1 & $1(1.8 \%)$ \\
\hline \multicolumn{2}{|l|}{ Stage } \\
\hline III & $20(35.1 \%)$ \\
\hline IV & $37(64.9 \%)$ \\
\hline \multicolumn{2}{|l|}{ Adjuvant therapy } \\
\hline None & $19(33.3 \%)$ \\
\hline Radiotherapy & $2(3.5 \%)$ \\
\hline Chemotherapy & $32(56.1 \%)$ \\
\hline Chemoradiotherapy & $4(7.0 \%)$ \\
\hline
\end{tabular}

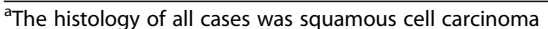

distributed as follows: well-differentiated SCC $(n=$ $30)$, moderately differentiated SCC $(n=25)$ and poorly differentiated SCC $(n=2)$. Thirty-eight patients $(66.6 \%)$ received adjuvant therapy as follows: 32 received chemotherapy (uracil/tegafur [ $n=29]$, tegafur $[n=2]$, cisplatin $+5-\mathrm{FU}[n=1]), 2$ received radiotherapy and 4 received chemoradiotherapy; the chemotherapy regimens were: uracil/tegafur $(n=1)$, TS-1 $(n=1)$, cisplatin $(n=1)$ and nedaplatin $(n=1)$. 


\section{Assessment of $\mathrm{CD} \mathrm{a}^{+} \mathrm{DCs}$ and their correlations with clinicopathological factors}

An infiltration of $\mathrm{CD} \mathrm{a}^{+} \mathrm{DCs}$ was observed in all 57 cases, with various densities in areas adhering to or adjacent to tumor cells. The average number of tumor-infiltrating $\mathrm{CD}^{+} \mathrm{a}^{+} \mathrm{DCs}$ was 47 (range 1.3-351). Using the median value (29) of the number of infiltrating CD1a ${ }^{+}$DCs as the cut-off, we divided the cases into the CD1a-low group $(n=29)$ and the CD1a-high group $(n=28)$. Representative histological images from each group are shown in Fig. 2.

The relationships between $\mathrm{CD} \mathrm{a}^{+} \mathrm{DC}$ infiltration and clinicopathological factors are summarized in Table 2. Details of $\mathrm{CD} \mathrm{a}^{+} \mathrm{DC}$ and $\mathrm{T}$ - or N-stage (CD1a-high case no., CD1a-low case no.) were as following: T1 $(2,2), \mathrm{T} 3(15,7), \mathrm{T} 4(12,19)$, N0 $(20,17)$, $\mathrm{N} 1(4,1), \mathrm{N} 2(5,9), \mathrm{N} 3(0,1)$. We divided the cases into $\mathrm{T} 2 / \mathrm{T} 3$ vs $\mathrm{T} 4$, and N0 vs N1-3 for the statistical analyses because of the balance of case numbers. The CD1a-high group had significantly more advanced (T4 and Stage IV) cases $(P=0.045$ and $P=0.038$, respectively) than the CD1a-low group. No significant difference was observed between the CD1a-low and CD1ahigh groups for other factors, i.e., age, sex, smoking, alcohol consumption, primary site, histological differentiation, $\mathrm{T}$ stage, $\mathrm{N}$ stage, $\mathrm{M}$ stage or adjuvant therapy.

\section{Assessment of $\mathrm{S} 100^{+} \mathrm{DCs}$ and their correlations with clinicopathological factors}

Infiltration of $\mathrm{S} 100^{+}$DCs was observed in all 57 cases at various densities. The average number of tumorinfiltrating $\mathrm{S}_{100}{ }^{+} \mathrm{DCs}$ was 69 (range 0.5-390). Using the median value (49) of $\mathrm{S} 100^{+} \mathrm{DCs}$ as the cut-off, we divided the cases into a S100-low group $(n=29)$ and a S100-high group $(n=28)$. Representative histological images from each group are shown in Fig. 3. The relationships between $\mathrm{S} 100^{+} \mathrm{DC}$ infiltration and clinicopathological factors are summarized in Table 3. Compared to the S100-low group, the S100-high group had significantly more cases of welldifferentiated SCC $(P=0.012)$. No significant differences were found for other factors (age, sex, smoking, alcohol drinking, primary site, $\mathrm{T}$ stage, $\mathrm{N}$ stage, $\mathrm{M}$ stage or adjuvant therapy) between the S100-low and S100-high groups.

\section{Assessment of $\mathrm{CD8}^{+}$CTLs and their association with $\mathrm{CD} 1 \mathrm{a}^{+}$and $\mathrm{S} 100^{+} \mathrm{DCs}$}

The average number of tumor-infiltrating $\mathrm{CD}^{+}$ CTLs was 563 (range $0-2,580$ ). The results of the linear regression analysis between $\mathrm{CD} \mathrm{a}^{+} \mathrm{DCs}$ or $\mathrm{S}_{100^{+}} \mathrm{DCs}$ and $\mathrm{CD}^{+}$CTLs are illustrated in Fig. 4. No significant association were observed between tumor-infiltrating $\mathrm{CD} \mathrm{a}^{+} \mathrm{DCs}$ and $\mathrm{CD}^{+} \mathrm{CTLs}$, or between tumor-infiltrating $\mathrm{S} 100^{+} \mathrm{DCs}$ and $\mathrm{CD} 8^{+}$
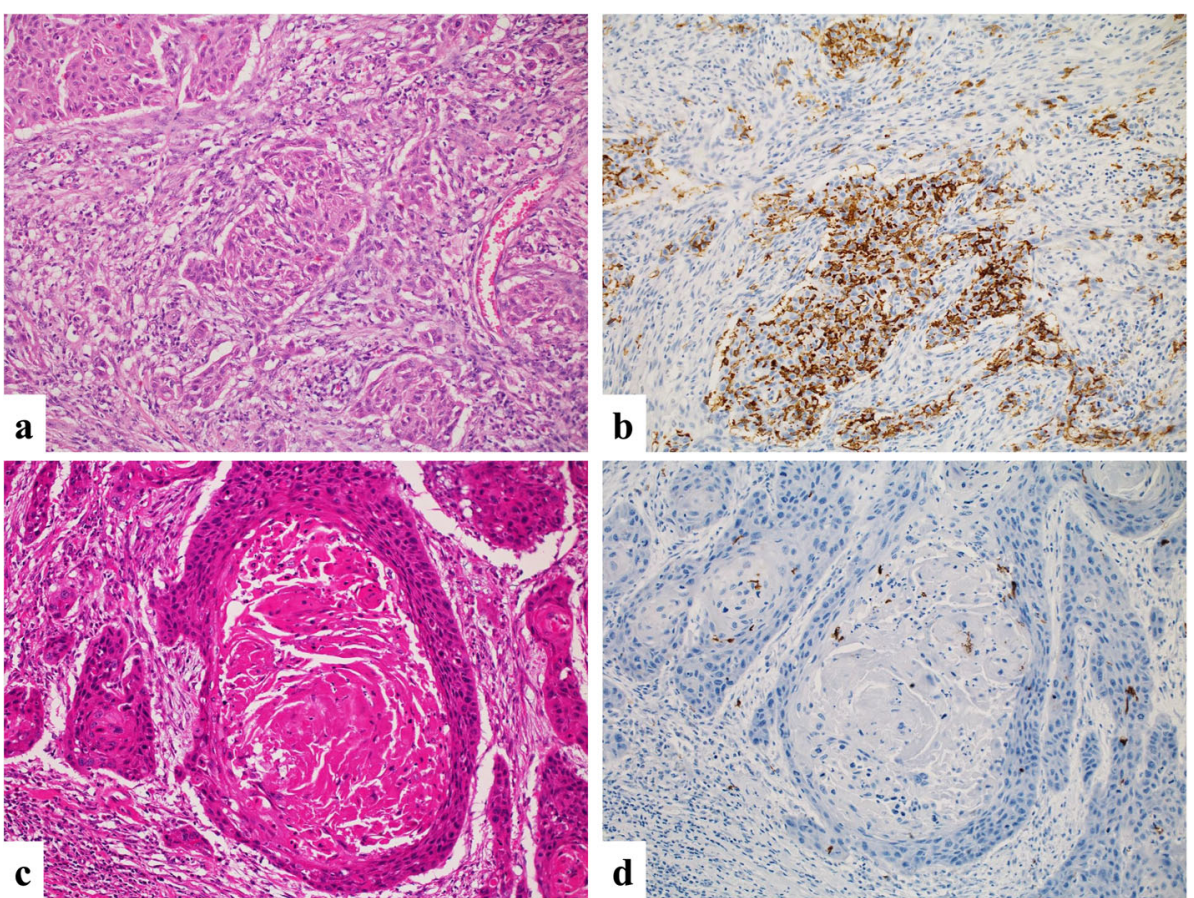

Fig. 2 Representative histological images of $\mathrm{CD} \mathrm{a}^{+} \mathrm{DC}$ infiltration into laryngeal squamous cell carcinoma. a Hematoxylin and eosin (HE)-stained image of a CD1a-high case ( $\times 200)$. $\mathbf{b} \mathrm{IHC}$ of CD1a in a CD1a-high case $(\times 200)$. Numerous CD1a ${ }^{+}$DCs can be observed. $\mathbf{c}$ IHC of a CD1a-low case ( $\times 200)$. $\mathbf{d} 1 \mathrm{HC}$ of CD1a in a CD1a-low case $(\times 200)$. Few CD1a ${ }^{+}$DCs are present 
Table 2 Clinicopathological features per $\mathrm{CD}_{1 a^{+}} \mathrm{DC}$ infiltration

\begin{tabular}{|c|c|c|c|}
\hline & $\begin{array}{l}\text { CD1a Low } \\
(n=29)\end{array}$ & $\begin{array}{l}\text { CD1a High } \\
(n=28)\end{array}$ & $P$-value \\
\hline Age, years (mean $\pm S D)$ & $68.9 \pm 8.4$ & $67.9 \pm 9.3$ & 0.682 \\
\hline \multicolumn{4}{|l|}{ Sex } \\
\hline Male & $28(96.6 \%)$ & $26(92.9 \%)$ & \multirow[t]{2}{*}{0.532} \\
\hline Female & $1(3.4 \%)$ & $2(7.1 \%)$ & \\
\hline \multicolumn{4}{|l|}{ Subsite } \\
\hline Glottic & $17(58.6 \%)$ & $18(64.3 \%)$ & \multirow[t]{2}{*}{0.661} \\
\hline Supra/Sub & $12(41.4 \%)$ & $10(35.7 \%)$ & \\
\hline \multicolumn{4}{|l|}{ Histology } \\
\hline Well & $16(55.2 \%)$ & $14(50.0 \%)$ & \multirow[t]{2}{*}{0.696} \\
\hline Mode/poor & $13(44.8 \%)$ & $14(50.0 \%)$ & \\
\hline \multicolumn{4}{|l|}{ T stage } \\
\hline $\mathrm{T} 2 / \mathrm{T} 3$ & $17(58.6 \%)$ & $9(32.1 \%)$ & \multirow[t]{2}{*}{0.045} \\
\hline T4 & $12(41.4 \%)$ & 19 (67.9\%) & \\
\hline \multicolumn{4}{|l|}{ N stage } \\
\hline NO & $20(69.0 \%)$ & $17(60.7 \%)$ & \multirow[t]{2}{*}{0.514} \\
\hline$N 1-3$ & $9(31.0 \%)$ & $11(39.3 \%)$ & \\
\hline \multicolumn{4}{|l|}{ M stage (\%) } \\
\hline MO & $28(96.6 \%)$ & $28(100.0 \%)$ & \multirow[t]{2}{*}{0.321} \\
\hline M1 & $1(3.4 \%)$ & $0(0.0 \%)$ & \\
\hline \multicolumn{4}{|l|}{ Stage } \\
\hline III & $14(48.3 \%)$ & $6(21.4 \%)$ & \multirow[t]{2}{*}{0.034} \\
\hline IV & $15(51.7 \%)$ & $22(78.6 \%)$ & \\
\hline $\mathrm{CD}^{+} \mathrm{CTLS}$ & $510.7 \pm 582.6$ & $616.7 \pm 415.6$ & 0.428 \\
\hline \multicolumn{4}{|l|}{ Adjuvant therapy } \\
\hline$(-)$ & $8(27.6 \%)$ & $11(39.3 \%)$ & \multirow[t]{2}{*}{0.349} \\
\hline$(+)$ & $21(72.4 \%)$ & $17(60.7 \%)$ & \\
\hline
\end{tabular}

CTLs. We divided the cases into a CD8-low group $(n=28)$ and a CD8-high group $(n=29)$ using the median value of $\mathrm{CD}^{+}$CTLs (435) as the cut-off value. No significant differences in clinicopathological factors were observed between these groups.

\section{Kaplan-Meier survival curves according to the infiltration of DCs and $\mathrm{CD}^{+}$CTLs}

The Kaplan-Meier survival curves, based on the status of $\mathrm{CD}^{+}{ }^{+} \mathrm{DCs}, \mathrm{S}_{100}{ }^{+} \mathrm{DC}$ and $\mathrm{CD} 8^{+} \mathrm{CTLs}$, are shown in Fig. 5. The CD1a-low group had significantly better DSS and OS than the CD1a-high group $(P=0.008$ and 0.032 , respectively). No significant difference was found between the S100-low group and S100-high group $(P=$ 0.310 and $P=0.511)$ or between the CD8-low group and CD8-high group $(P=0.258$ and $P=0.505)$ for both DSS and OS.

\section{Univariate and multivariate analyses for OS and DSS}

The results of the univariate analyses for OS and DSS are summarized in Table 4 . The factors significantly correlated with $\mathrm{OS}$ were tumor subsite, $\mathrm{T}$ stage, $\mathrm{N}$ stage and infiltration of CD1a ${ }^{+}$DCs $(P=0.046, P=0.008, P=$ $0.003, P=0.035$, respectively). The factors significantly correlated with DSS were T stage, $\mathrm{N}$ stage and infiltration of $\mathrm{CD}^{2} \mathrm{a}^{+} \mathrm{DCs}(P=0.000, P=0.024, P=0.009$, respectively).

The factors that were shown to be significant in the univariate analyses were further subjected to multivariate analysis (Table 5). The multivariate analysis for OS indicated that $\mathrm{T}$ stage, $\mathrm{N}$ stage and infiltration of $\mathrm{CD} \mathrm{a}^{+}$DCs were each significantly associated with the patients' OS $(P=0.026, P=0.007$, $P=0.013$, respectively). The multivariate analysis for DSS indicated that $\mathrm{T}$ stage, $\mathrm{N}$ stage and infiltration of $\mathrm{CD}_{1 \mathrm{a}}{ }^{+} \mathrm{DCs}$ were significantly associated with the 


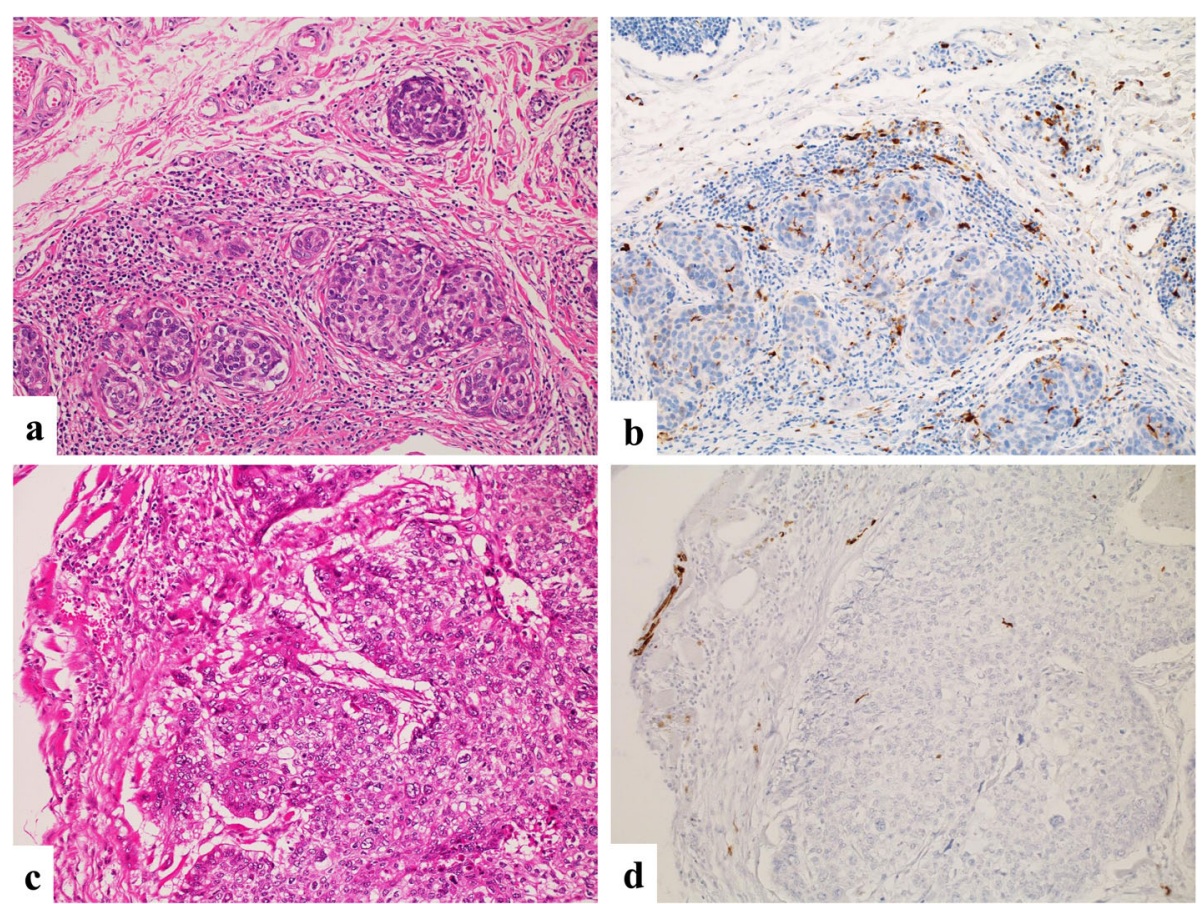

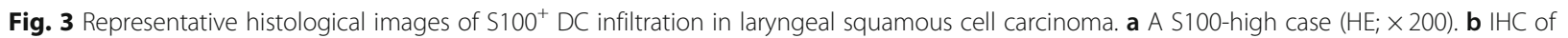
S100 in an S100-high case $(\times 200)$. c A S100-low case $(H E ; \times 200)$. d IHC of S100 in a S100-low case $(\times 200)$

patients' DSS $(P=0.001, P=0.021$ and $P=0.009$, respectively).

\section{Discussion}

We investigated the infiltration of $\mathrm{CD}_{1 \mathrm{a}}{ }^{+} \mathrm{DCs}$ and its association with clinicopathological factors in patients with advanced laryngeal cancer who underwent a total laryngectomy as an initial treatment. $\mathrm{CD}_{1}{ }^{+}$DCs infiltration was significantly associated with more advanced (T4 and Stage IV) cases. Unexpectedly, the CD1a-high group showed unfavorable clinical outcomes and it was an independent prognostic factor in multivariate analyses which involved TMN staging, whereas tumor-infiltrating $\mathrm{S} 100^{+} \mathrm{DCs}$ were not significantly associated with clinical outcomes. As $\mathrm{S} 100^{+}$DCs represent both mature and immature DCs, our results indicated that immature $\mathrm{CD} 1 \mathrm{a}^{+}$ DCs likely have more influence on the prognosis than mature DCs. Similar results suggesting a significant effect on survival after immature $\mathrm{CD} \mathrm{a}^{+} \mathrm{DCs}$ infiltration into tumor compared to mature DCs have been reported for several body organs [15-17].

It has been speculated that a higher density of $\mathrm{CD} \mathrm{a}^{+}$ DCs in tumor tissue correlates with favorable clinical outcomes, and several studies have reported that tumorinfiltrating $\mathrm{CD}^{+}{ }^{+} \mathrm{DCs}$ were associated with favorable clinical outcomes in carcinomas of various organs [1317]. However, conflicting results have also been published. Hilly et al. [19] reported that higher CD1a ${ }^{+}$DCs infiltration around a tumor was associated with a greater risk of recurrence in surgically treated cases of early squamous cell carcinoma of the tongue. Lundgren et al. [20] reported that a high density of infiltrating $\mathrm{CD} \mathrm{a}^{+}$ DCs was an unfavorable prognostic factor in a pancreato-biliary type of periampullary adenocarcinoma. One of the possible reasons for this discrepancy in findings are the widely varying methods used to evaluate $\mathrm{CD}_{1 \mathrm{a}}{ }^{+} \mathrm{DCs}$ in previous reports. Taken together, the past and present findings show that the relationship between tumor-infiltrating $\mathrm{CD} \mathrm{a}^{+} \mathrm{DCs}$ and clinical outcomes in patients with malignancies remains controversial.

Our literature search revealed 4 studies that investigated tumor-infiltrating DCs in laryngeal cancer, and 3 of these 4 studies investigated $\mathrm{S} 100^{+}$DCs only. Yilmaz et al. [21] and Gallo et al. [22] reported that a high density of tumor-infiltrating $\mathrm{S} \mathrm{O}^{+} \mathrm{DCs}$ was associated with favorable patient outcomes. However, Karakök et al. reported that the infiltration of $\mathrm{S} 100^{+} \mathrm{DCs}$ was not associated with survival, although it was significantly associated with the inflammatory response [23]. This result is consistent with our analysis of $\mathrm{S} 100^{+}$DCs. Only 1 of these 4 previous studies investigated $\mathrm{CD}^{+} \mathrm{a}^{+} \mathrm{DC}$ infiltration in laryngeal cancer. Esteban et al. focused on $\mathrm{CD} 1 \mathrm{a}\left(\mathrm{OKT}^{+}\right) \mathrm{DCs}$ and reported that the infiltration of $\mathrm{CD}_{1 \mathrm{a}}{ }^{+}$DCs was not associated with survival, although it was significantly associated with lymphocyte infiltration [24]. Thus, the present study, we believe, is the first to 
Table 3 Clinicopathological features per $S 100^{+}$DC infiltration

\begin{tabular}{|c|c|c|c|}
\hline & $\begin{array}{l}\text { S100 Low } \\
(n=29)\end{array}$ & $\begin{array}{l}\text { S100 High } \\
(n=28)\end{array}$ & $P$-value \\
\hline Age, years (mean $\pm S D)$ & $68.4 \pm 10.0$ & $68.4 \pm 7.6$ & 0.995 \\
\hline \multicolumn{4}{|l|}{$\operatorname{Sex}(\%)$} \\
\hline Male & $28(96.6 \%)$ & $26(92.9 \%)$ & \multirow[t]{2}{*}{0.532} \\
\hline Female & $1(3.4 \%)$ & $2(7.1 \%)$ & \\
\hline \multicolumn{4}{|l|}{ Subsite } \\
\hline Glottic & $19(65.5 \%)$ & $16(57.1 \%)$ & \multirow[t]{2}{*}{0.516} \\
\hline Supra/sub & $10(34.5 \%)$ & $12(42.9 \%)$ & \\
\hline \multicolumn{4}{|l|}{ Histology } \\
\hline Well & $20(69.0 \%)$ & $10(35.7 \%)$ & \multirow[t]{2}{*}{0.012} \\
\hline Mode/poor & $9(31.0 \%)$ & $18(64.3 \%)$ & \\
\hline \multicolumn{4}{|l|}{ T stage (\%) } \\
\hline $\mathrm{T} 2 / \mathrm{T} 3$ & $12(41.4 \%)$ & $14(50.0 \%)$ & \multirow[t]{2}{*}{0.514} \\
\hline T4 & $17(58.6 \%)$ & $14(50.0 \%)$ & \\
\hline \multicolumn{4}{|l|}{ N stage (\%) } \\
\hline No & $22(75.9 \%)$ & $15(53.6 \%)$ & \multirow[t]{2}{*}{0.078} \\
\hline $\mathrm{N} 1-3$ & $7(24.1 \%)$ & $13(46.4 \%)$ & \\
\hline \multicolumn{4}{|l|}{ M stage (\%) } \\
\hline Mo & $28(96.6 \%)$ & $28(100.0 \%)$ & \multirow[t]{2}{*}{0.322} \\
\hline M1 & $1(3.4 \%)$ & $0(0.0 \%)$ & \\
\hline \multicolumn{4}{|l|}{ Stage } \\
\hline III & $11(37.9 \%)$ & $9(32.1 \%)$ & \multirow[t]{2}{*}{0.647} \\
\hline IV & $18(62.1 \%)$ & $19(67.9 \%)$ & \\
\hline $\mathrm{CD}^{+}$CTLs & $499.2 \pm 513.6$ & $628.6 \pm 498.2$ & 0.541 \\
\hline \multicolumn{4}{|l|}{ Adjuvant therapy } \\
\hline$(-)$ & $11(37.9 \%)$ & $8(28.6 \%)$ & \multirow[t]{2}{*}{0.454} \\
\hline$(+)$ & $18(62.1 \%)$ & $20(71.4 \%)$ & \\
\hline
\end{tabular}

report an association between poor surgical outcomes and tumor infiltrating $\mathrm{CD} \mathrm{a}^{+} \mathrm{DCs}$ in laryngeal cancer.

It is generally considered that immature DCs capture the tumor antigen, mature and then present the antigen to naïve $\mathrm{T}$ cells, which induces a cellular immune response involving $\mathrm{CD}^{+}$CTLs [25]. In the present study, the number of $\mathrm{CD}^{+}$CTLs appeared to be greater in the $\mathrm{CD} 1 \mathrm{a}^{+} \mathrm{DC}$-high group, although the result did not reach statistical significance. A possible explanation of the correlation of the adverse effect of $\mathrm{CD} \mathrm{a}^{+} \mathrm{DCs}$ is that $\mathrm{CD}_{1} \mathrm{a}^{+} \mathrm{DCs}$ have a specific but unknown function other than antigen presentation that accelerates the
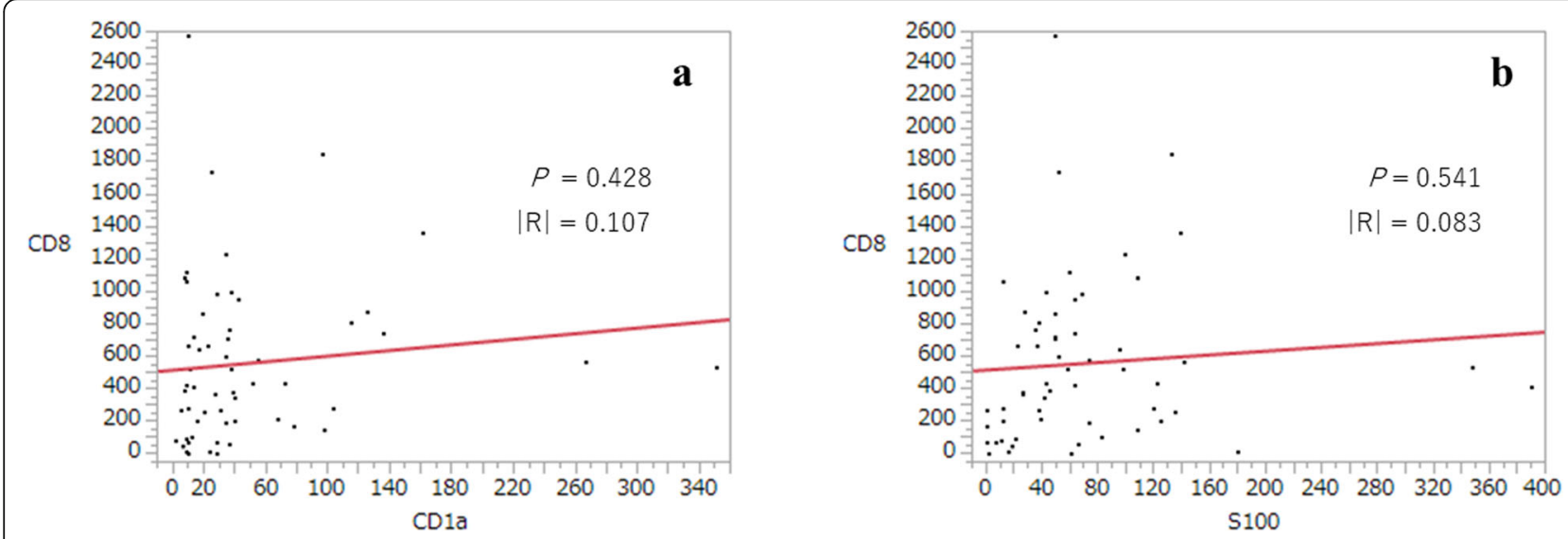

Fig. 4 Linear regression analyses. a between CD1a ${ }^{+}$DCs and CD8 ${ }^{+}$CTLs and $\mathbf{b}$ between $S 100^{+}$DCS and CD8 ${ }^{+}$CTLS 


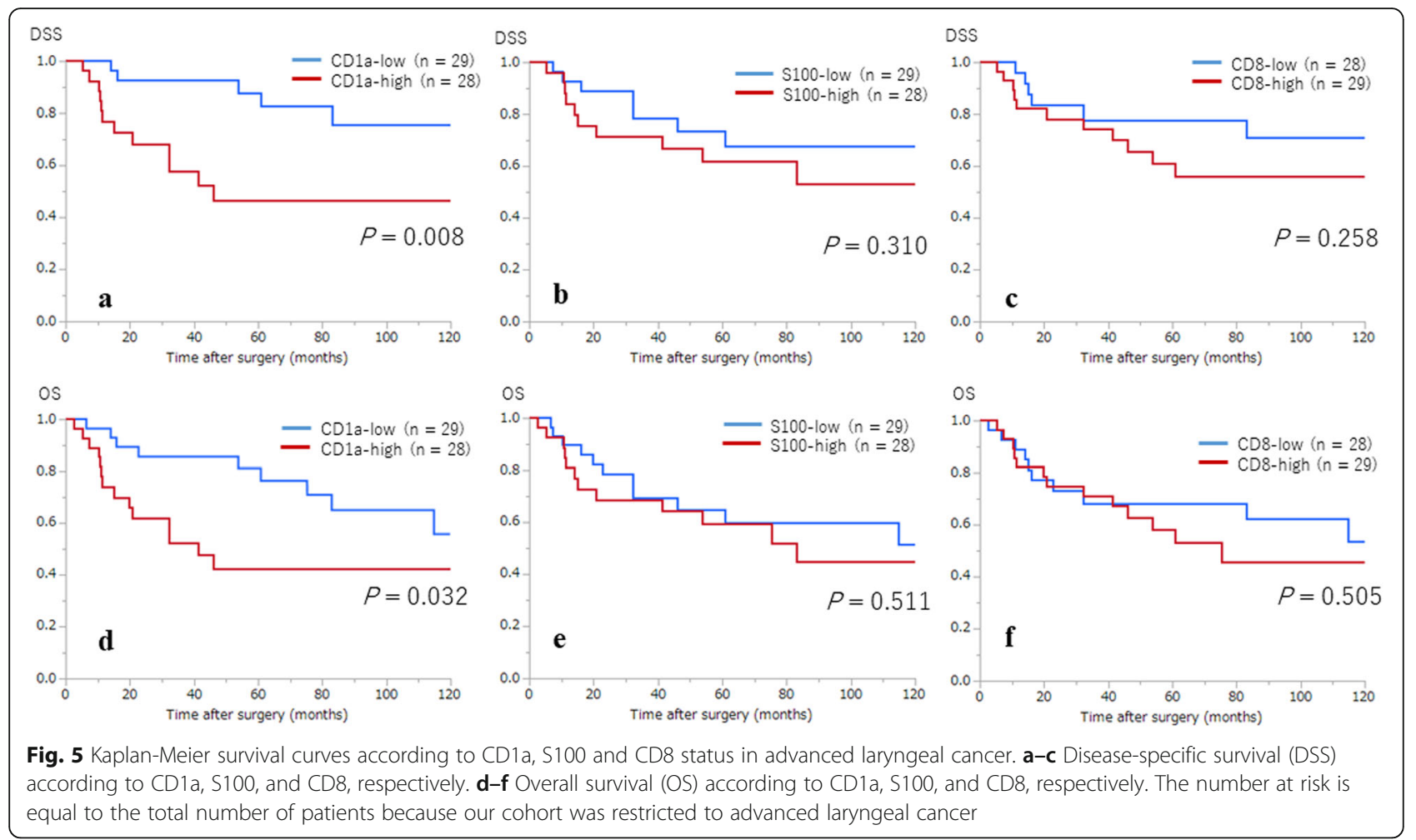

progression of cancer cells. It can also be hypothesized that the function of $\mathrm{CD} \mathrm{a}^{+} \mathrm{DCs}$ in tumor tissue may differ according to the organ or histological cell type. As it is known that there are many subsets of DCs with unique and specific functions [26], these hypotheses seem plausible. However, the role(s) of $\mathrm{CD}_{1} \mathrm{a}^{+} \mathrm{DCs}$ in cancer tissue remain to be unequivocally established, as do the reasons why the invasion of $\mathrm{CD} 1 \mathrm{a}^{+} \mathrm{DCs}$ is correlated with a poor prognosis of patients with advanced laryngeal cancer.

Recent studies have reported that high-CD8 ${ }^{+}$CTLs infiltration was associated with better prognosis of patients with laryngeal cancer [27, 28]. However, our study did not find a significant association between $\mathrm{CD}^{+}$CTLs infiltration and prognosis. Possible reasons for this discrepancy are different sample sizes and different selection criteria for patients. In contrast to previous research, the present study excluded neoadjuvant cases because the microenvironment of tumors may be different between treatment naïve and neoadjuvant cases. We considered treatment naïve cases were more suitable for this study because there is a paucity of knowledge about the role(s) of $\mathrm{CD} \mathrm{a}^{+}$ DCs in laryngeal cancer. Another possible reason is a difference in the assessment method for $\mathrm{CD} 8^{+}$CTLs. Although there is no consensus at present, further studies will contribute to the development of a unified method and the optimal cut-off assessment of $\mathrm{CD} 8^{+}$CTLs in laryngeal cancer.
It has been reported that head and neck SCC reduces the body's immunocompetence in multiple ways [29]. A malfunction or decrease of plasmacytoid dendritic cells (pDCs) in tumor tissue is considered to be one of the causes of reduced immunocompetence because pDCs produce interferon (IFN), which plays an important role in antitumor immunity [30]. However, in contrast, without stimulation (e.g., by viruses), $\mathrm{T}$ cell derived CD40 ligand activates $\mathrm{pDCs}$, and these activated pDCs support the functions of regulatory $\mathrm{T}$ cells and contribute to immunotolerance [31, 32]. O'Donnell et al. reported that an intratumoral increase of Langerin-positive immature DCs was significantly associated with vascular/lymphatic invasion and unfavorable survival in patients with oral SCC. They also found that the presence of CD123positive pDCs was associated with a poor prognosis [33]. Thus, a malignancy's microenvironment, which is induced and regulated by the immune system, is extremely complex and most of the functions and potential interactions among various subsets of DCs remain to be elucidated.

The limitations of the present study are its retrospective nature, the relatively small number of patients treated at a single center, and the long period required for enrollment. The treatment policy for neoadjuvant therapy is ununified and detailed information on the recurrence/metastatic lesion rates and treatment for these lesions are regrettably unavailable for our patient cohort. In addition, the immunohistochemical analyses were 
Table 4 Univariate analyses for disease specific-survival and overall survival $(n=57)$

\begin{tabular}{|c|c|c|c|c|c|}
\hline \multirow[t]{2}{*}{ Characteristic } & \multirow[t]{2}{*}{$\mathrm{n}$} & \multicolumn{2}{|l|}{ DSS } & \multicolumn{2}{|l|}{ OS } \\
\hline & & $\mathrm{HR}(95 \% \mathrm{Cl})$ & $P$-value & $\mathrm{HR}(95 \% \mathrm{Cl})$ & $P$-value \\
\hline Age & & & 0.919 & & 0.789 \\
\hline$\leq 67$ years & 28 & 1 & & 1 & \\
\hline$>67$ years & 29 & $1.05(0.40-2.73)$ & & $1.12(0.49-2.55)$ & \\
\hline Sex & & & 0.315 & & 0.081 \\
\hline Female & 3 & 1 & & 1 & \\
\hline Male & 54 & $0.29(0.04-2.25)$ & & $0.20(0.05-0.89)$ & \\
\hline Subsite & & & 0.149 & & 0.046 \\
\hline Glottic & 35 & 1 & & 1 & \\
\hline Supra/sub & 22 & $2.02(0.78-5.25)$ & & $2.31(1.01-5.28)$ & \\
\hline Histology & & & 0.575 & & 0.937 \\
\hline Well & 30 & 1 & & 1 & \\
\hline Mode/poor & 27 & $0.76(0.29-2.00)$ & & $1.03(0.45-2.35)$ & \\
\hline T stage & & & 0.000 & & 0.008 \\
\hline $\mathrm{T} 2 / \mathrm{T} 3$ & 26 & 1 & & 1 & \\
\hline $\mathrm{T} 4$ & 31 & $8.93(2.04-39.18)$ & & $3.24(1.27-8.25)$ & \\
\hline N stage & & & 0.024 & & 0.003 \\
\hline No & 37 & 1 & & 1 & \\
\hline $\mathrm{N} 1-3$ & 20 & $3.05(1.17-7.93)$ & & $3.58(1.56-8.19)$ & \\
\hline M stage & & & 0.436 & & 0.530 \\
\hline Mo & 56 & 1 & & 1 & \\
\hline M1 & 1 & $2.50(0.33-19.01)$ & & $2.04(0.27-15.32)$ & \\
\hline Adjuvant therapy & & & 0.269 & & 0.571 \\
\hline$(-)$ & 19 & 1 & & 1 & \\
\hline$(+)$ & 38 & $1.83(0.59-5.61)$ & & $1.29(0.53-3.14)$ & \\
\hline$C D 1 a^{+} \mathrm{DCs}$ & & & 0.009 & & 0.035 \\
\hline Low & 43 & 1 & & 1 & \\
\hline High & 14 & $3.76(1.31-10.74)$ & & $2.45(1.05-5.70)$ & \\
\hline $\mathrm{S} 100^{+} \mathrm{DCs}$ & & & 0.416 & & 0.672 \\
\hline Low & 39 & 1 & & 1 & \\
\hline High & 18 & $1.49(0.57-3.92)$ & & $1.19(0.52-2.72)$ & \\
\hline $\mathrm{CD} 8^{+}$CTLS & & & 0.253 & & 0.504 \\
\hline Low & 33 & 1 & & 1 & \\
\hline High & 24 & $1.77(0.65-4.84)$ & & $1.33(0.58-3.06)$ & \\
\hline
\end{tabular}

DSS Disease-specific survival, OS Overall survival

Table 5 Multivariate analyses for disease specific and overall survival $(n=57)$

\begin{tabular}{llll}
\hline Type & Characteristic & HR (95\%Cl) & P-value \\
\hline DSS & CD1a (high) & $4.03(1.32-12.29)$ & 0.009 \\
& T stage (T4) & $8.48(1.89-37.98)$ & 0.001 \\
& N stage (positive) & $3.21(1.21-8.57)$ & 0.021 \\
OS & CD1a (high) & $3.14(1.24-7.95)$ & 0.013 \\
& Subtype (glottic) & $0.47(0.19-1.13)$ & 0.090 \\
& T stage (T4) & $2.78(1.07-7.22)$ & 0.026 \\
& N stage (positive) & $3.23(1.38-7.54)$ & 0.007 \\
\hline
\end{tabular}


performed using only one representative section of cancer tissue, and therefore the entire tumor tissue was not evaluated.

\section{Conclusions}

We have analyzed the association between the infiltration of $\mathrm{CD}^{-} \mathrm{a}^{+} \mathrm{DCs}$ into cancer tissue and clinicopathological factors in patients with advanced laryngeal cancer. Our results demonstrated that $\mathrm{CD} \mathrm{a}^{+} \mathrm{DC}$ infiltration was associated with a poor clinical outcome, and was an independent prognostic factor, revealed by multivariate analyses. The mechanism of $\mathrm{CD}^{2} \mathrm{a}^{+} \mathrm{DCs}$ leading to unfavorable clinical outcomes remains to be clarified. We anticipate that further studies will validate our findings and ultimately elucidate the function(s) of tumorinfiltrating $\mathrm{CD} \mathrm{a}^{+} \mathrm{DCs}$ in advanced laryngeal cancer.

\section{Abbreviations}

CTL: Cytotoxic T-lymphocyte; DC: Dendritic cell; DSS: Disease-specific survival; IHC: Immunohistochemistry; OS: Overall survival; SCC: Squamous cell carcinoma

\section{Acknowledgements}

Not applicable.

\section{Authors' contributions}

Conceptualization, project administration: KK and SA; data curation and formal analysis: $\mathrm{AM}$ and $\mathrm{KK}$; validation: $\mathrm{KK}, \mathrm{YK}$ and $\mathrm{SA}$; writing of the original draft: AM and KK; writing review and final editing: KK, YK and SA. The author(s) read and approved the final manuscript.

\section{Funding}

This study was partly supported by the Japan Society for the Promotion of Science (JSPS) Grants-in-Aid for Scientific Research C (KAKENHI grant numbers JP20K07408). The funding bodies played no role in the design of the study and collection, analysis, and interpretation of data and in writing the manuscript.

\section{Availability of data and materials}

The datasets generated and/or analyzed during the current study are not publicly available due to the specifics of the patients' informed consent and because the study's ethics approval did not cover this issue, but they are available from the corresponding author on reasonable request.

\section{Declarations}

\section{Ethics approval and consent to participate}

Comprehensive informed consent for the use of resected tissue for research was obtained from all patients and the study protocol was approved by the Ethics Committee of the Faculty of Medicine at Saga University (No. 202004-R-19).

\section{Consent for publication}

Not applicable.

\section{Competing interests}

The authors have no conflicts of interest to declare.

\section{Author details}

${ }^{1}$ Department of Pathology \& Microbiology, Saga University Faculty of Medicine, Saga, Japan. ${ }^{2}$ Department of Otolaryngology - Head \& Neck Surgery, Saga University Faculty of Medicine, Saga, Japan. ${ }^{3}$ Department of Pathology, Saga University Hospital, Nabeshima 5-1-1, Saga City, Saga 849-8501, Japan.
Received: 17 August 2020 Accepted: 23 August 2021

Published online: 30 August 2021

\section{References}

1. Cooper JS, Porter K, Mallin K, Hoffman HT, Weber RS, Ang KK, et al. National Cancer Database report on cancer of the head and neck: 10-year update. Head Neck. 2009;31(6):748-58. https://doi.org/10.1002/hed.21022.

2. Hori M, Matsuda T, Shibata A, Katanoda K, Sobue T, Nishimoto H. Japan Cancer Surveillance Research Group. Cancer incidence and incidence rates in Japan in 2009: A study of 32 population-based cancer registries for the Monitoring of Cancer Incidence in Japan (MCIJ) project. Jpn J Clin Oncol. 2015;45:884-91. https://doi.org/10.1093/jjco/hyv088.

3. Matsuda T, Ajiki W, Marugame T, loka A, Tsukuma H, Sobue T, et al. Population-based survival of cancer patients diagnosed between 1993 and 1999 in Japan: a chronological and international comparative study. Jpn J Clin Oncol. 2011;41(1):40-51. https://doi.org/10.1093/jjco/hyq167.

4. Iwai $Y$, Ishida M, Tanaka Y, Okazaki T, Honjo T, Minato N. Involvement of PDL1 on tumor cells in the escape from host immune system and tumor immunotherapy by PD-L1 blockade. Proc Natl Acad Sci U S A. 2002;99(19): 12293-7. https://doi.org/10.1073/pnas.192461099.

5. Rabinovich GA, Gabrilovich D, Sotomayor EM. Immunosuppressive strategies that are mediated by tumor cells. Annu Rev Immunol. 2007;25(1):267-96. https://doi.org/10.1146/annurev.immunol.25.022106.141609.

6. Ueno H, Klechevsky E, Morita R, Aspord C, Cao T, Matsui T, et al. Dendritic cell subsets in health and disease. Immunol Rev. 2007;219(1):118-42. https:// doi.org/10.1111/j.1600-065X.2007.00551.X.

7. Banchereau J, Steinman RM. Dendritic cells and the control of immunity. Nature. 1998;392(6673):245-52. https://doi.org/10.1038/32588.

8. Jego G, Pascual V, Palucka AK, Banchereau J. Dendritic cells control B cell growth and differentiation. Curr Dir Autoimmun. 2005;8:124-39. https://doi. org/10.1159/000082101.

9. Fujii S, Shimizu K, Kronenberg M, Steinman RM. Prolonged IFN-gammaproducing NKT response induced with alpha-galactosylceramide-loaded DCs. Nat Immunol. 2002;3(9):867-74. https://doi.org/10.1038/ni827.

10. Lucas M, Schachterle W, Oberle K, Aichele P, Diefenbach A. Dendritic cells prime natural killer cells by trans-presenting interleukin 15. Immunity. 2007; 26(4):503-17. https://doi.org/10.1016/j.immuni.2007.03.006.

11. Donato R, Cannon BR, Sorci G, Riuzzi F, Hsu K, Weber DJ, et al. Functions of S100 proteins. Curr Mol Med. 2013;13(1):24-57. https://doi.org/10.2174/1 56652413804486214

12. Coventry B, Heinzel S. CD1a in human cancers: a new role for an old molecule. Trends Immunol. 2004;25(5):242-8. https://doi.org/10.1016/j.it.2 004.03.002.

13. Eisenthal A, Polyvkin N, Bramante-Schreiber L, Misonznik F, Hassner A, Lifschitz-Mercer B. Expression of dendritic cells in ovarian tumors correlates with clinical outcome in patients with ovarian cancer. Hum Pathol. 2001; 32(8):803-7. https://doi.org/10.1053/hupa.2001.26455.

14. Goldman SA, Baker E, Weyant RJ, Clarke MR, Myers JN, Lotze MT. Peritumoral CD1a-positive dendritic cells are associated with improved survival in patients with tongue carcinoma. Arch Otolaryngol Head Neck Surg. 1998;124(6):641-6. https://doi.org/10.1001/archotol.124.6.641.

15. Jardim JF, Gondak R, Galvis MM, Pinto CAL, Kowalski LP. A decreased peritumoral CD1a+ cell number predicts a worse prognosis in oral squamous cell carcinoma. Histopathology. 2018;72(6):905-13. https://doi. org/10.1111/his.13415.

16. Hilly O, Rath-Wolfson L, Koren R, Mizrachi A, Hamzany Y, Bachar G, et al. CD1a-positive dendritic cell density predicts disease-free survival in papillary thyroid carcinoma. Pathol Res Pract. 2015;211(9):652-6. https://doi.org/10.1 016/j.prp.2015.05.009.

17. Kai K, Tanaka T, Ide T, Kawaguchi A, Noshiro H, Aishima S. Immunohistochemical analysis of the aggregation of CD1a-positive dendritic cells in resected specimens and its association with surgical outcomes for patients with gallbladder cancer. Transl Oncol. 2021;14(1): 100923. https://doi.org/10.1016/j.tranon.2020.100923.

18. Brierley JD, Gospodarowicz MK, Wittekind C, editors. Union for International Cancer Control: TNM classification of malignant tumours. 8th ed. Oxford: Wiley Blackwell; 2017. p. 31-5.

19. Hilly O, Strenov Y, Rath-Wolfson L, Hod R, Shkedy Y, Mizrachi A, et al. The predictive value of dendritic cells in early squamous cell carcinoma of the tongue. Pathol Res Pract. 2016;212(12):1138-43. https://doi.org/10.1016/j. prp.2016.09.011. 
20. Lundgren S, Karnevi E, Elebro J, Nodin B, Karlsson MCl, Eberhard J, et al. The clinical importance of tumour-infiltrating macrophages and dendritic cells in periampullary adenocarcinoma differs by morphological subtype. J Transl Med. 2017;15(1):152. https://doi.org/1 0.1186/s12967-017-1256-y.

21. Yilmaz T, Gedikoglu G, Celik A, Onerci M, Turan E. Prognostic significance of Langerhans cell infiltration in cancer of the larynx. Otolaryngol Head Neck Surg. 2005;132(2):309-16. https://doi.org/10.1016/j.otohns.2004.04.018.

22. Gallo O, Libonati GA, Gallina E, Fini-Storchi O, Giannini A, Urso C, et al. Langerhans cells related to prognosis in patients with laryngeal carcinoma. Arch Otolaryngol Head Neck Surg. 1991;117(9):1007-10. https://doi.org/10.1 001/archotol.1991.01870210079015.

23. Karakök M, Bayazit YA, Ucak R, Ozer E, Kanlikama M, Mumbuc S, et al. Langerhans cell related inflammatory reaction in laryngeal squamous cell carcinoma. Auris Nasus Larynx. 2003;30(1):81-4. https://doi.org/10.1016/s03 85-8146(02)00025-1.

24. Esteban F, Ruiz-Cabello F, Gonzalez-Moles MA, Lopez-Gonzalez MA, Funez R, Redondo M. Clinical significance of langerhans cells in squamous cell carcinoma of the larynx. J Oncol. 2012;2012:753296-5. https://doi.org/10.11 55/2012/753296

25. Banchereau J, Palucka AK. Dendritic cells as therapeutic vaccines against cancer. Nat Rev Immunol. 2005;5(4):296-306. https://doi.org/10.1038/nri1592.

26. Geissmann F, Manz MG, Jung S, Sieweke MH, Merad M, Ley K. Development of monocytes, macrophages, and dendritic cells. Science. 2010;327:656-61. https://doi.org/10.1126/science.1178331 Erratum in: Science. 2010;330:1319.

27. Chatzopoulos K, Kotoula V, Manoussou K, Markou K, Vlachtsis K, Angouridakis $\mathrm{N}$, et al. Tumor infiltrating lymphocytes and CD8+ T cell subsets as prognostic markers in patients with surgically treated laryngeal squamous cell carcinoma. Head Neck Pathol. 2020;14(3):689-700. https://doi. org/10.1007/s12105-019-01101-6.

28. Hoesli R, Birkeland AC, Rosko AJ, Issa M, Chow KL, Michmerhuizen NL, et al. Proportion of CD4 and CD8 tumor infiltrating lymphocytes predicts survival in persistent/recurrent laryngeal squamous cell carcinoma. Oral Oncol. 2018; 77:83-9. https://doi.org/10.1016/j.oraloncology.2017.12.003.

29. Young MR. Protective mechanisms of head and neck squamous cell carcinomas from immune assault. Head Neck. 2006;28(5):462-70. https://doi. org/10.1002/hed.20331.

30. Hartmann E, Wollenberg B, Rothenfusser S, Wagner M, Wellisch D, Mack B, et al. Identification and functional analysis of tumor-infiltrating plasmacytoid dendritic cells in head and neck cancer. Cancer Res. 2003;63(19):6478-87.

31. Gilliet M, Liu YJ. Generation of human CD8 T regulatory cells by CD40 ligand-activated plasmacytoid dendritic cells. J Exp Med. 2002;195(6):695704. https://doi.org/10.1084/jem.20011603.

32. Rissoan MC, Soumelis V, Kadowaki N, Grouard G, Briere F, de Waal MR, et al. Reciprocal control of $\mathrm{T}$ helper cell and dendritic cell differentiation. Science. 1999:283(5405):1183-6. https://doi.org/10.1126/science.283.5405.1183.

33. O'Donnell RK, Mick R, Feldman M, Hino S, Wang Y, Brose MS, et al. Distribution of dendritic cell subtypes in primary oral squamous cell carcinoma is inconsistent with a functional response. Cancer Lett. 2007; 255(1):145-52. https://doi.org/10.1016/..canlet.2007.04.003.

\section{Publisher's Note}

Springer Nature remains neutral with regard to jurisdictional claims in published maps and institutional affiliations.

Ready to submit your research? Choose BMC and benefit from:
- fast, convenient online submission
- thorough peer review by experienced researchers in your field
- rapid publication on acceptance
- support for research data, including large and complex data types
- gold Open Access which fosters wider collaboration and increased citations
- maximum visibility for your research: over 100M website views per year
At BMC, research is always in progress.
Learn more biomedcentral.com/submissions

